\title{
Correction to: Software engineering whispers: The effect of textual vs. graphical software design descriptions on software design communication
}

\author{
Rodi Jolak ${ }^{1}$ (D) - Maxime Savary-Leblanc ${ }^{2}$ - Manuela Dalibor ${ }^{3}$ - Andreas Wortmann ${ }^{3}$. \\ Regina Hebig ${ }^{1}$ • Juraj Vincur ${ }^{4} \cdot$ Ivan Polasek $^{4} \cdot$ Xavier Le Pallec $^{2} \cdot$ Sébastien Gérard $^{5}$. \\ Michel R. V. Chaudron ${ }^{1}$
}

Published online: 26 October 2020

(C) The Author(s) 2020

\section{Correction to: Empirical Software Engineering https://doi.org/10.1007/s10664-020-09835-6}

To fulfill the contractual requirement of the Sweden Compact agreement, the following funding note has to be added and placed in the Funding section of the original article: Open access funding provided by University of Gothenburg.

The original article has been corrected.

Open Access This article is licensed under a Creative Commons Attribution 4.0 International License, which permits use, sharing, adaptation, distribution and reproduction in any medium or format, as long as you give appropriate credit to the original author(s) and the source, provide a link to the Creative Commons licence, and indicate if changes were made. The images or other third party material in this article are included in the article's Creative Commons licence, unless indicated otherwise in a credit line to the material. If material is not included in the article's Creative Commons licence and your intended use is not permitted by statutory regulation or exceeds the permitted use, you will need to obtain permission directly from the copyright holder. To view a copy of this licence, visit http://creativecommons.org/licenses/by/4.0/.

Publisher's note Springer Nature remains neutral with regard to jurisdictional claims in published maps and institutional affiliations.

The online version of the original article can be found at https://doi.org/10.1007/s10664-020-09835-6

Rodi Jolak

rodi.jolak@cse.gu.se

Chalmers | University of Gothenburg, Gothenburg, Sweden

2 Lille University, Lille, France

3 RWTH Aachen University, Aachen, Germany

4 Slovak University of Technology, Bratislava, Slovakia

5 CEA LIST, Palaiseau, France 